\title{
MENGEMBANGKAN NILAI NASIONALISME, PATRIOTISME, DAN TOLERANSI MELALUI ENRICHMENT DALAM PEMBELAJARAN SEJARAH TENTANG PERANAN YOGYAKARTA SELAMA REVOLUSI KEMERDEKAAN
}

\author{
Murdiyah Winarti \\ Departemen Pendidikan Sejarah, FPIPS, Universitas Pendidikan Indonesia \\ murdiyahwinarti@upi.edu
}

\begin{abstract}
The declaration of independence in August 1945 is the beginning for Indonesian to participate as a free nation and to prosper the people by nurturing the sense of unity and the development of one united nation. History is the most important subject in curriculum, without overriding any other subjects, to nurture the values of nationalism, patriotism, and tolerance as basic for one integrated nation. In the view of the researcher, one of the topics the students learn is a period of independence revolution in Yogyakarta during 1945 - 1950. Unfortunately, it is not sufficiently discussed in the textbook. The researcher views that from the period young generation can learn many lessons for the present life and use them to participate in the efforts to fulfil the aims of independence, as showed by the historical figures of the period.

Abstrak: $\quad$ Kemerdekaan yang diproklamasikan sejak Agustus 1945 merupakan modal bagi bangsa Indonesia memulai perjuangan untuk mengisi kemerdekaan dengan membangun rakyatnya agar sejahtera dengan menanamkan perasaan persatuan dan kesatuan sebagai bangsa. Sejarah merupakan mata pelajaran yang paling penting, tanpa bermaksud mengesampingkan pelajaran lainnya, untuk melahirkan perasaan kuat tentang itu, menyangkut nilai-nilai nasionalisme, patriotisme, dan toleransi dalam mewujudkan integrasi bangsa. Salah satu topik yang menurut peneliti sangat penting untuk dipelajari oleh generasi muda (siswa), namun tidak banyak disinggung dalam buku pegangan mereka yakni tentang masa revolusi kemerdekaan di Yogyakarta tahun 1945-1950. Peristiwa ini sarat dengan nilai-nilai kehidupan bagi generasi muda untuk mengisi kemerdekaan ini dengan sebaik-baiknya, seperti yang telah ditorehkan oleh generasi sebelumnya.
\end{abstract}

Kata kunci: Nasionalisme, Patriotisme, toleransi, enrichment

\section{PENDAHULUAN}

Bermula dari adanya keresahan dengan banyaknya peristiwa yang mengoyak kehidupan berbangsa pada awal abad ke XXI, maka peneliti mencoba mengembangkan materi sejarah sebagai enrichment untuk mengembangkan nilai-nilai nasionalisme, patriotisme, dan toleransi. Dewasa ini tantangan yang harus dihadapi oleh masyarakat semakin kompleks, dalam proses pertumbuhan kebudayaan nasional muncul nilai-nilai baru sebagai akibat modernisasi dan globalisasi seperti materialisme, konsumerisme, hedonisme dan sebagainya. Gejala-gejala ini perlu dihadapi dengan nilai-nilai religius, dan idealisme terutama berasal dari nasionalisme, karena masih dapat memunculkan kekuatan sosial politik untuk menghadapi aspek negatif tersebut.

Sesudah lebih dari 70 tahun Indonesia menikmati kemerdekaan, seharusnya setiap warga negaranya memiliki kesadaran nasional yang tinggi. Salah satu uapaya untuk mengembangkan nilai-nilai tersebut adalah melalui 'dunia' pendidikan dengan materi sejarah sebagai kajiannya. Dari hal tersebut diharapkan akan menumbuhkan kesadaran nasional yang berbentuk loyalitas kepada bangsa dan negara.
Seperti diketahui bahwa kajian sejarah tidak semata-mata untuk kepentingan masa lampau itu sendiri, tetapi untuk memberikan 'pelajaran' kepada manusia agar bisa hidup lebih baik di masa sekarang maupun yang akan datang. Yang dimaksudkan dengan pelajaran di sini adalah sebagai pendidikan, suatu sumbangan praktis sejarah untuk segisegi pengetahuan, kemampuan, keterampilan, serta afektif siswa (Sjamsuddin, 2005, hlm. 177). Dengan mengambil salah satu peristiwa sejarah periode revolusi kemerdekaan, khususnya yang berlangsung di Yogyakarta, diharapkan akan memperkenalkan siswa kepada pengalaman kolektif dan masa lalu bangsanya. Selanjutnya diharapkan akan membangkitkan kesadaran dalam kaitannya dengan kehidupan bersama dalam komunitas yang lebih besar.

Pengajaran sejarah di setiap jenjang pendidikan mengandung tugas untuk menanamkan semangat berbangsa dan bertanah air. Sejarah termasuk salah satu di antara ilmu-ilmu sosial yang ikut bertanggung jawab terhadap pembentukan warga negara yang baik, namun tampaknya belum memperlihatkan peranannya yang optimal dalam upaya tersebut. Kurang optimalnya dalam menjalankan perannya 
antara lain dapat disebabkan karena berbagai faktor seperti: konten kurikulum kurang memanfaatkan sumber belajar, strategi, pendekatan, ataupun metode pembelajarannya yang kurang bervariatif. Sejarah merupakan disiplin ilmu yang penting, meskipun oleh sebagian kalangan dipahami bukan sebagai ilmu sosial yang sesungguhnya, karena proses keilmuannya lebih dekat dengan humaniora. Materi dalam pembelajaran sejarah yang menjelaskan perjuangan manusia di masa lalu harus memiliki potensi untuk dipelajari dan diterapkan dalam kehidupan masa kini agar lebih bermakna.

Dalam pembelajaran sejarah ada banyak nilai yang dapat ditanamkan antara lain seperti: nilai informatif, nilai pendidikan, nilai budaya, nilai etika, nilai nasionalisme dan sebagainya (Kochhar, 2008: 54-63). Nilai-nilai di atas merupakan sumber pembelajaran sejarah yang dapat dikembangkan serta ditingkatkan pada diri siswa di berbagai jenjang pendidikan. Dengan kata lain pendidikan tetap merupakan wahana yang tepat dan strategis dalam menanamkannya, sedangkan sekolah adalah tempat untuk mengembangkan nilai-nilai tersebut (Wiriaatmadja, 2002, hlm. 156). Sementara itu sejarah bernilai karena menyediakan kesempatan bagi siswa untuk mengenal masa lalu, selain itu salah satu fungsi penting dari sejarah adalah pengabdian pengalaman masyarakat masa lampau yang sewaktu-waktu dapat membantu pemecahan masalah (Renier, 1961, hlm. 14). Sejarah sendiri menyangkut persoalan kesinambungan dan perubahan, banyak pelajaran yang diperoleh, sehingga tidak ingin mengulangi kesalahan-kesalahan yang telah diperbuat pada masa lalu, sedangkan keberhasilan tentu perlu dicontoh dan kalau bisa ditingkatkan lagi (Wineburg, 2006: vii).

Dalam hal ini memahami sejarah tidak hanya mengetahui peristiwa yang sudah terjadi, tetapi juga kemampuan membuat proyeksi agar tidak terjadi kesalahan, belajar sejarah merupakan cara atau jalan menjadikan bijaksana/ arif sebelum kejadian berlangsung, atau yang sering disebut sebagai belajar dari sejarah (Sjamsuddin, 2012, hlm. 285). Bekal yang diperlukan dari pembelajaran sejarah adalah belajar dengan berorientasi kepada pengembangan potensi berfikir siswa, yang menyentuh emosinya dalam hubungannya antar manusia, menyadarkan dirinya akan bangsa dan tanah air, selain itu juga menghargai keanekaragaman bangsa-bangsa dan kebudayaan-kebudayaan yang ada dalam melengkapkan kemanusiaaannya (Wiriaatmadja, 2002:146).

Melihat peran pentingnya mata pelajaran sejarah, maka menjadi sebuah tanggungjawab dan tantangan yang besar untuk menumbuhkan serta meningkatkan kesadaran sejarah dikalangan generasi muda pada khususnya. Diawali dengan keinginan mewariskan pengalaman masa lalu menyangkut halhal yang baik/ kejayaan maupun kekalahan atau kehancuran dari setiap peristiwa yang pernah dialami manusia dari masa ke masa. Hal tersebut merupakan pengetahuan yang berharga, untuk menghadapi kehidupan yang terus berlanjut selain juga bagi pengembangan potensi berfikir siswa itu sendiri. Berkaitan dengan hal tersebut siswa dapat mengembangkan kecintaan, kesetiaan, ataupun ketaatan kepada negara melalui pengetahuan dan apresiasi dan pemahaman tentang perjuangan orang-orang yang berkonstribusi dalam membangun bangsa yang besar dan kuat (Jarolimek, 1986:146).

Melalui penelitian ini dilakukan suatu kajian yang dapat mengembangkan nasionalisme, patriotisme, dan toleransi dengan mengambil materi sejarah lokal, dengan tema pokok revolusi kemerdekaan di Yogyakarta. Diharapkan akan memperkaya pembelajaran sejarah dan selanjutnya dapat mengajak generasi muda khususnya siswa SMA meningkatkan kecintaan, kesetiaan dan ketaatan kepada negara untuk terlibat aktif dalam pembangunan bangsa. Apa yang pernah dilakukan dan dialami oleh masyarakat tersebut dapat menjadi pengetahuan berharga, yang bagi pendidikan sejarah diperlukan dalam membangun berbagai nilai positif pada diri siswa (Hasan, 2012:125).

Peristiwa yang terjadi di Yogyakarta berkaitan erat atas kelangsungan NKRI serta untuk melihat bagaimana mengembangkan nasionalisme, patriotisme, dan toleransi dilakukan di persekolahan. Pembelajaran sejarah lokal akan terasa lebih mudah dihayati, karena materinya menyangkut kejadian penting yang dialamai secara langsung oleh lingkungannya, dengan kata lain siswa diajak ke situasi riil tentang masa lalunya. Akan memperkenalkan siswa kepada pengalaman kolektif dan masa lalu bangsanya, selanjutnya akan membangkitkan kesadaran dalam kaitannya dengan kehidupan bersama dalam komunitas yang lebih besar. Dengan menfokuskan pada peranan Yogyakarta sebagai pusat integrasi bangsa Indonesia selama revolusi kemerdekaan tahun 1945-1950, tentunya banyak nilai-nilai kehidupan yang dapat dipetik dari masa lalu (materi sejarah) tersebut.

Peranan dari Yogyakarta selama periode revolusi kemerdekaan, sangat terbatas dikemukakan sebagai materi pembelajaran sejarah di jenjang pendidikan SMA. Pembahasan tentang keberadaan Yogyakarta sebagai ibukota RI dan perananya selama revolusi kemerdekaan masih sedikit disinggung. Sebagai salah satu enrichment pembelajaran sejarah, nantinya diharapkan dapat memberikan pengetahuan dan pemahaman yang lebih luas, dibandingkan yang tercatat dalam buku teks. Selain itu dapat menyadarkan siswa akan adanya proses perubahan dan perkembangan masyarakat, yang akan menjelaskan jati diri bangsa di masa lalu, masa kini dan masa depan ditengah-tengah perubahan dunia, melalui perluasan materi sejarah lokal. Tidak mungkin mengesampingkan peranannya, karena pada waktu itu Yogyakarta merupakan wilayah RI yang dengan tegas tetap setia pada cita-cita proklamasi. Yogyakarta menjadi saksi dari adanya suatu peristiwa yang dinamakan Pemerintahan Transisi atau Masa Peralihan yang belum banyak diungkap dalam berbagai tulisan yang berhubungan dengan periode tersebut.

Berangkat dari kondisi tersebut menjadi suatu tantangan untuk mengembangkan materi dari salah satu aspek peristiwa sejarah lokal sebagai enrichment pembelajaran sejarah yang diharapkan dapat mengembangkan nilai-nilai nasionalisme, patriotisme, dan toleransi segenap generasi muda. Dalam pembelajaran sejarah, materi yang dikemas secara baik dapat membangkitkan kesadaran empatik dikalangan siswa, 
yaitu sikap simpati dan toleransi terhadap orang lain, serta membangkitkan kesadaran akan kehidupan bersama sebagai sebuah bangsa. Pengetahuan tentang sejarah didukung oleh pengalaman yang nyata dalam praktek kewarganegaraan tidak terbantahkan memberikan konstribusi membantu anakanak mengenali dirinya dengan latarbelakang sejarah yang mereka miliki (Jarolimek, 1986: 146). Proses pengenalan diri inilah merupakan titik awal dari timbulnya rasa harga diri, kebersamaan, keterikatan, rasa memiliki serta rasa bangga terhadap bangsa dan tanah airnya (Wiriaatmadja, 2002: 156).

\section{KAJIAN PUSTAKA}

Revolusi kemerdekaan di Indonesia sering disebut dengan revolusi fisik, yang berarti dalam rangka mempertahankan kemerdekaan didominasi oleh kekerasan. Senada dengan hal tersebut Ricklef (2008: 318) menyatakan bahwa: "Dalam perjalanan sejarah bangsa Indonesia kurun waktu 1945-1949 dikenal dengan Masa Revolusi Fisik. Bagi pihak Indonesia revolusi fisik ini bertujuan untuk menyempurnakan proses penyatuan dan kebangkitan nasional yang telah lama berlangsung...... Pada masa revolusi, untuk pertama kalinya dalam sejarah bangsa Indonesia mengalami sentuhan nasionalisme serentak, dan spontan dalam merealisasikan cita-cita bersama sebagaimana yang dinyatakan dalam teks proklamasi kemerdekaan Indonesia. Suasana revolusi bukan saja saat ketika segala aturan yang normal dijadikan tidak berlaku, tetapi juga suasana yang memperlihatkan keterlibatan politik dari massa yang banyak, luas serta intens (Abdullah, 2001, hlm. 44). Revolusi nasional adalah saluran utama dari patriotisme, ketika seluruh rakyat berjuang untuk mempertahankan negara yang telah dimiliki (Abdullah, 2001, hlm. 45).

Sementara itu terkait dengan prinsip-prinsip nasionalisme yang dimaksud seperti diungkapkan oleh Kartodirdjo (Nursam, 2008: 325) ialah menyangkut kepatuhan, kebebasan, kesetaraan personalitas, kepribadian bangsa, dan prestasi. Dalam hal ini tampaknya memperlihatkan bahwa nasionalisme dapat dibangun kapan saja dan dimana saja selama itu diraih melalui perjuangan dan pengorbanan, memiliki jiwa, semangat dalam menghadapi tantangan. Nasionalisme sering dihubungkan dengan patriotisme, dan istilah-istilah ini digunakan bersinonim satu dengan yang lainnya. Meskipun demikian, nasionalisme ialah sejenis ideologi, namun selalu memupuk nilai-nilai patriotik sebagai sikap yang sewajarnya. Bahkan, dapat dikatakan revolusi nasional adalah saluran utama dari patriotisme yang berkaitan dengan sifat atau jiwa kepahlawanan, sikap gagah berani pantang menyerah, dan rela berkorban dami bangsa dan negara.

Patriotisme adalah sikap yang bersumber dari perasaan cinta tanah air yakni semangat kebangsaan dan nasionalisme, sehingga menimbulkan kerelaan berkorban untuk bangsa dan negaranya. Patriotisme adalah sikap yang bersumber dari perasaan cinta tanah air yakni semangat kebangsaan dan nasionalisme, sehingga menimbulkan kerelaan berkorban untuk bangsa dan negaranya (http://id.wikipedia. org/ wiki/ Patriotisme). Perwujudan sikap patriotisme dapat dilaksanakan pada masa darurat (perang) dan masa damai di Indonesia adalah pasca kemerdekaan. Sikap patriotisme pada masa darurat dapat diwujudkan dengan cara mengangkat senjata, ikut berperang secara fisik melawan penjajah, menjadi petugas dapur umum, ikut membantu korban dll. Pada masa damai sikap patriotisme dapat diwujudkan dengan cara: menegakkan hukum dan kebenaran, memajukan pendidikan, memberantas kebodohan atau kemiskinan, meningkatkan kemampuan diri secara optimal, memelihara persaudaraan/ persatuan dan lainnya. Selanjutnya semangat kebangsaan (nasionalisme dan patriotisme) dapat diterapkan di lingkungan terdekat seperti keluarga, sekolah dan masyarakat sekitar dengan cara melalaui: keteladanan, pewarisan dan ketokohan lokal secara nyata, terus menerus dan konsisten.

Berikutnya, toleransi adalah istilah dalam konteks sosial, budaya dan agama yang berarti sikap dan perbuatan yang melarang adanya diskriminasi terhadap kelompokkelompok yang berbeda atau tidak dapat diterima oleh mayoritas dalam suatu masyarakat (http://id.wikipedia.org/ wiki/Toleransi). Toleransi merupakan kebajikan moral yang dapat mengurangi kebencian, karena dengan toleransi akan dapat memperlakukan orang lain secara baik, hormat, dan penuh pengertian. Dengan kata lain, toleransi tidak melarang seseorang untuk melakukan suatu penilaian terhadap orang lain, melainkan menuntut seseorang agar menghargai perbedaan yang ada di setiap individu. Senada dengan yang dikemukakan dalam Konferensi Declaration of Principles on Tolerance yang diselengarakan UNESCO di Perancis tanggal 16 November 1995 sebagai berikut.

Tolerance is respect, acceptance and appreciation of the rich diversity of our world's culture, our forms of expression and ways of being human. It is fostered by knowledge, openness, communication and freedom of thought, conscience and belief. Tolerance is harmony in difference. Is it not only a moral duty, it is also a political and legal requirement. Tolerance, the virtue that makes peace possible, contributes to the replacement of the culture of war by a culture of peace. (http://portal.unesco.org/en/ev.php-URL

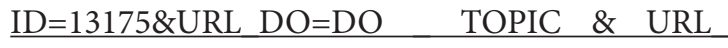
$\underline{\text { SECtion }=201 . h t m l)}$

Toleransi adalah harmoni atau keselarasan dalam perbedaan, tidak semata untuk kewajiban moral, akan tetapi juga dalam kehidupan politik dan hukum. Dengan kata lain bahwa toleransi adalah perilaku terbuka dan menghargai segala perbedaan yang ada dengan sesama. Oleh sebab itu, sikap toleransi perlu dikembangkan manusia sebagai mahluk sosial dan akan menciptakan adanya kerukunan hidup, karena dalam toleransi sikap saling menghormati dan menghargai orang lain sangat ditekankan.

Sementara itu sebagai materi sejarah lokal yang memiliki dimensi nasional, Daerah Istimewa Yogyakarta merupakan tempat pusat perjuangan Indonesia pada masa revolusi kemerdekaan. Tidak mudah memang untuk merumuskan sejarah lokal, tapi tidak perlu dipusingkan atau dipermasalahkan tentang rumusan tersebut, seperti dikemukakan Finberg and 
Skipp (1973, hlm. vii) yang mengatakan: 'We don't know what we mean by local history, and we don't care; but we mean to go on with it'. Sejarah lokal juga disebutkan sebagai studi tentang kehidupan masyarakat atau khususnya komunitas dari suatu lingkungan sekitar (neighborhood) tertentu dalam dinamika perkembangannya dalam berbagai aspek kehidupan manusia (Widja, 1991: 15), sedangkan Finberg lebih khusus menyebutkan; suatu komunitas, township atau village (Finberg, 1973).

Sejarah lokal dengan sederhana dapat dirumuskan sebagai kisah/ceritra tentang masa lampau dari kelompok-kelompok mayarakat yang berada pada daerah geografis yang terbatas. Rumusan sederhana ini juga dipergunakan untuk menjelaskan sejarah lokal pada tulisan ini, sejarah yang menceritakan dinamika kehidupan dari suatu komunitas masyarakat dengan kultur yang dimilikinya di suatu wilayah, regionalitas tertentu. Beberapa sejarawan telah mendefinisikan dan memberikan pemahaman tentang apa yang dimaksud dengan sejarah lokal, meskipun begitu belum ditemukan kesepakatan bulat tentangnya. Menarik juga apa yang dikatakan sejarawan Taufik Abdulah dalam bukunya 'Sejarah Lokal di Indonesia", bahwa pengertian kata lokal adalah sederhana yakni tempat, ruang atau suatu locality yang ditentukan oleh 'perjanjian' yang diajukan oleh penulis sejarah sendiri (Abdullah, 2010:15).

Adapun yang dimaksudkan dengan istilah enrichment pembelajaran sejarah dengan mengambil materi tentang revolusi kemerdekaan di Yogyakarta adalah merupakan upaya memperkaya nilai-nilai nasionalisme, patriotisme, dan toleransi. Diharapkan siswa akan memiliki pengetahuan lebih banyak, lebih kaya di bidang tertentu (sejarah), dibandingkan dengan para siswa yang tidak mengikuti pengayaan. Pengayaan atau enrichment mempunyai fungsi memberikan pelayanan kepada siswa yang memiliki kemampuan di atas rata-rata dengan memperhatikan substansi pelajaran maupun segi metode pengajaran yang berbeda dari buku teks. Pendidikan yang optimal membutuhkan pengalaman yang menantang bagi siswa sehingga proses asimilasi dan akomodasi dapat menghasilkan pertumbuhan intelektualnya. Fungsi dari enrichment adalah memfasilitasi siswa berbakat agar mereka dapat mengoptimalkan kemampuan belajarnya, dalam hal ini adalah pelajaran sejarah. Dengan memberikan materi enrichment, di harapkan mereka memiliki pemahaman yang lebih baik tentang pelajaran sejarah dan selanjutnya mampu mengembangkan nilai-nilai nasionalisme, patriotisme, dan toleransi dalam kehidupan keseharian mereka.

Model yang paling dikenal dan paling banyak diadopsi oleh model kurikulum antara lain adalah: Model pengayaan Triad, untuk keperluan penulisan ini model Triad yang dipilih, karena mudah dilaksanakan. Dalam hal ini siswa diperkenalkan dengan orang, tempat, peristiwa dan lainnya yang merupakan perluasan dan pendalaman materi dari kurikulum reguler. Dengan menggunakan model ini, dapat dilihat bagaimana aktivitas siswa di dalam kelas antara lain dalam menggali pengetahuan, pemahaman, keterampilan belajar, berfikir, dan berkomunikasi. tentang salah satu topik sejarah yang telah dikembangkan terkait dengan peranan Yogyakarta selama revolusi kemerdekaan tahun 1945-1950.
Hampir semua aktivitas pengayaan (enrichment) tujuannya adalah untuk merangsang pengetahuan yang lebih tinggi, kreativitas, keterampilan berpikir lainnya, pembelajaran dengan motivasi dari diri, dan hasrat akan pendidikan dan karier tinggi (Davis, 2012: 156). Selain itu juga dikatakan tujuan dari diadakannya pengayaan (enrichment) ini adalah untuk memberikan kesempatan kepada siswa yang mengikutinya mencapai perkembangan yang optimal dari bakat atau kemampuan yang ada pada dirinya (Buchori, 1995: 191). Dengan pengayaan ini siswa dengan bakat dan minat pada bidang sejarah dapat mengembangkan pengetahuan serta wawasan kesejarahan yang lebih dalam daripada apa yang dapat dicapai oleh siswa yang tidak mengikuti pengayaan di bidang sejarah ini. Sebagai salah satu pengayaan (enrichment) pembelajaran sejarah, topik tersebut harus dipelajari dengan seksama oleh seluruh siswa dalam satu kelas. Untuk melihat lebih jauh bahwa materi sejarah dengan topik revolusi kemerdekaan tersebut layak sebagai pengayaan, maka perlu dilakukan wawancara di luar jam pelajaran dengan beberapa siswa tentang keluasan dan kedalamannya.

\section{PEMBAHASAN}

Penulisan sejarah atau historiografi itu menyangkut paparan, penyajian, presentasi atau penampilan/eksposisisi, sampai kepada dan dibaca oleh para pembaca atau pemerhati sejarah (Sjamsuddin, 2012: 236). Namun pada umumnya dalam buku teks penyajiannya kurang memperhatikan perbedaan individual siswa yang unggul, dengan siswa yang memiliki kemampuan rata-rata atau di bawah rata-rata (Muslich, 2010: 30). Sementara itu perlu dilakukan penulisan kembali materi ajar didasarkan pada beberapa pertimbangan antara lain: bahwa materi yang dikembangkan tidak banyak dijelaskan dalam buku teks sekolah yang memang hanya menjelaskan hal-hal yang dianggap penting secara garis besar saja, dan buku teks tersebut diperuntukkan bagi semua siswa SMA tanpa ada perbedaan. Oleh karena itu, pengembangan materi ajar sebagai pengayaan diharapkan menarik para siswa untuk membacanya, dan selanjutnya dapat menumbuhkan minat mereka untuk mengkaji lebih jauh materi yang sedang dipelajari tersebut.

Secara lebih detail Brian Garvey dan Mary Krug (1977: 2-5) mengidentifikasi bahwa mempelajari sejarah mempunyai beberapa maksud di antaranya:

a) to acquire knowledge of historical facts,

b) to gain an understanding or appreciation of past events or periods or people,

c) to acquire the ability to evaluate and criticize historical writing,

d) to learn the techniques of historical research,

e) to learn how to write history.

Oleh sebab itu sebagai enrichment pembelajaran sejarah di SMA, materi ajar yang dimaksud harus dapat memenuhi kebutuhan mereka. Tidak hanya semata-mata belajar tentang fakta-fakta sejarah tetapi juga meningkatkan kemampuan dalam menilai dan mengkritisi karya sejarah. Enrichment 
dapat meningkatkan kemampuan berfikir tingkat tinggi siswa bila dipersiapkan dengan baik dan sesuai dengan kebutuhan mereka (Tan, W.C., dkk., 2006: 145). Siswa SMA dipersiapkan untuk melanjutkan studi ke jenjang yang lebih tinggi, oleh sebab itu harus diberikan perhatian yang lebih besar pada pengembangan kemampuan berfikir, kemampuan prosesual dan pengembangan kemampuan dalam mengambil inisiatif (Hasan, 2004: 20).

Dalam memaparkan ceritera tentang peranan Yogyakarta di masa revolusi kemerdekaan tidak hanya sekedar memuat materi pokok dalam aspek ruang lingkup, yang mendukung tercapainya Kompetensi Inti dan Kompetensi Dasar seperti yang telah dirumuskan dalam RPP. Dengan demikian pengembangan materi sejarah, tentang peranan Yogyakarta masa revolusi kemerdekaan tahun 1945-1950 sebagai sumber enrichment pembelajaran sejarah bagi siswa akan bermanfaat. Oleh sebab itu dalam narasinya perlu dikemukakan nilai-nilai yang sangat penting, antara lain seperti: nilai nasionalisme, patriotisme dan toleransi, sebagai perekat terwujudnya integrasi bangsa. Hal yang penting untuk dipahami bahwa dalam pendidikan nilai ranah afektif sangat diutamakan, yaitu belajar/mengajar yang membahas bidang emosi, perasaan, sikap, valensi, pilihan, dan hal-hal lain yang ada pada bidang estetis dan etis (Winecoff, 1987: 1-23). Berbagai nilai jelas sekali merupakan urusan persekolahan, seperti menghargai pengetahuan, keterampilan, berpikir kritis, pendidikan sepanjang hayat, warga negara yang baik, dan lain-lain. Adakalanya dalam keterpesonaan siswa atau mahasiswa terhadap sains dan teknologi membuatnya lupa terhadap kegunaan sejarah. Mereka lupa bahwa identifikasi dirinya, orang tua, darimana asalnya, apa yang sedang dikerjakan, dan antisipasi yang akan dilakukan di masa mendatang adalah berasal dan manfaat dari belajar sejarah (Wiriaatmadja, 2002: 18). Oleh sebab itu dalam mengembangkan materi sejarah sebagai sumber enrichment dengan menitik beratkan pada peranan Yogyakarta sebagai pusat daya sentripetal integrasi bangsa Indonesia, nilai-nilai yang berkaitan dengan nasionalisme, patriotisme, dan toleransi penting untuk dihadirkan.

Materi sejarah yang dikembangkan sebagai pengayaan menjabarkan substansi harus lebih luas menyangkut fakta, prinsip, konsep dan atau teori. Selain itu juga materi ajar tersebut menguraikan hal-hal yang berkaitan dengan dengan konsep, definisi, prosedur dan contoh. Sementara itu tingkat kesulitan dan kerumitan materi telah disesuaikan dengan tingkat perkembangan siswa SMA. Dalam teori psikologi dari Piaget yang erat hubungannya dengan perkembangan kognitif, mereka berada pada periode formal operations (mulai usia 12 tahun), terkait dengan kemampuan pengembangan berfikir sistematis dan logis mengenai materi-materi abstrak atau dapat memikirkan situasi hipotesis secara penuh (Hergenhahn \& Olson, 2009: 325). Dengan demikian tentunya siswa tidak akan mengalami kesulitan dalam membaca dan memahami isi materi ajar tersebut.

Dalam menghasilkan suatu karya historiografi (buku teks) yang diperuntukkan bagi siswa kiranya perlu memperhatikan hal-hal seperti: fakta (hal penting untuk melakukan rekonstruksi), sumber yang dipergunakan, penafsiran atau penjelasannya, kebijakan pendidikan yang berlaku, cara penyajian dan kelengkapan lainnya. Lebih jelas lagi adalah substansi faktualnya harus benarbenar dapat dipertanggungjawabkan secara akademik (ilmiah), sumber idealnya primary sources atau paling tidak sumber kedua; penafsiran dan atau penjelasan selain harus logis dan sistematis, secara akademis harus dapat dipertanggungjawabkan, memperhatikan visi atau kebijakan pendidikan maupun politik yang berlaku secara nasional, penyajian dan retorikanya (narasi) harus memperhatikan usia siswa; dan yang terakhir adalah berkaitan dengan kelengkapan ilustrasi, gambar, foto, peta-peta sejarah dalam layout yang informatif dan atraktif.

Persyaratan pokok dalam rangka mewujudkan integrasi bangsa adalah kesadaran nasional tentang pentingnya persatuan dari suatu bangsa yang serba majemuk seperti Indonesia. Sementara itu, negara sebagai organisasi politik dari bangsa Indonesia adalah merupakan suatu produk historis dan hanya dapat dipahami sifat-sifatnya apabila dijelaskan kembali seluruh perkembangan berbagai kehidupan politik-kultural yang berlangsung di masa lampau. Siswa perlu ditanamkan pengertian bahwa integrasi bangsa itu sangat penting karena bila proses integrasi gagal, maka negara kesatuan Indonesia akan terpecah-belah. Melalui pembelajaran sejarah, masalah integrasi perlu diterangkan dengan menceritakan bagaimana daerah-daerah (lokal) secara bertahap tercakup dalam kesatuan yang demikian besar dan akhirnya mewujudkan wilayah Indonesia seperti sekarang ini. Oleh sebab itu, membicarakan Indonesia sebagai kesatuan teritorial politik memerlukan penjelasan secara historis yang berintikan adanya proses integrasi daerah-daerah yang tersebar dari Sabang sampai Merauke.

Seperti dikatakan oleh Djoko Suryo (Kamarga, 2012: 42), bahwa kajian tentang proses dekolonisasi dan nasionalisasi serta integrasi dari masa awal kemerdekaan hingga sekarang belum sepenuhnya terselesaikan. Permasalahannya adalah bagaimanakah seharusnya historiografi Indonesia pada masa kini disusun atau ditulis agar dapat difungsikan untuk memperkuat proses integrasi bangsa dan ikatan NKRI?, sehingga integrasi yang muncul bersamaan dengan perjalanan sejarah bangsa tertanam/ tersosialisasikan dengan baik kepada siswa. Sejarah harus menginspirasi siswa untuk mencintai tanah airnya serta memberi pandangan yang jelas tentang perjalanan panjang dari masa lalu bangsanya tersebut.

Proses pengenalan diri yang meningkatkan menjadi kesadaran kolektif ini merupakan titik awal dari timbulnya rasa harga diri, rasa bangga dan rasa memiliki terhadap bangsa dan tanah airnya (Wiriaatmadja, 1992: 67-68). Melalui perjalanan sejarahnya dapat dikatakan bangsa ini sebagai bangsa pejuang, baik melalui cara kekerasan/ pejuangan bersenjata maupun diplomasi oleh para para intelektual melalui organisasiorganisasi kebangsaan. Adapun cara yang dilakukan untuk membangkitkan semangat nasionalisme diwarnai oleh jiwa dan semangat perjuangan dan penuh pengorbanan tanpa pamrih (the sentiment of the sacrifices). Sekarang apa yang telah dilakukan para pejuang tersebut sering disebut dengan 
nilai-nilai juang '45 (angkatan 45), sementara itu dalam kehidupan sehari-hari nilai-nilai itu sudah cenderung berkurang ditampilkan oleh para generasi penerus. Memang jiwa jaman telah berubah namun tantangan di sini tidak diartikan dalam pandangan sempit melawan penjajah atau kolonialisme, karena tantangan sekarang ini bentuknya lain seperti kemiskinan, kebodohan, korupsi, dll.

Beberapa nilai kehidupan seperti nasionalisme, patriotisme dan toleransi yang telah dicontohkan atau dilakukan oleh mereka yang hidup di masa lalu harus dapat dikomunikasikan dengan baik lewat tulisan. Oleh sebab itu semakin besar pula tuntutan akan perlunya meningkatkan mutu dari isi materi buku teks sejarah termasuk penyajian atau historiografinya. Pada akhirnya hasil pengembangan materi sejarah tentang periode revolusi kemerdekaan yang berlangsung di Yogyakarta tersebut diimplementasikan di SMA. Materi yang dikembangkan termasuk dalam kajian sejarah lokal berdimensi nasional, sehingga para pelaku sejarah beragam (lokal dan nasional) termasuk beberapa bagian peristiwa yang mengiringi, meskipun tempat kejadiannya dekat dengan kehidupan siswa yang tinggal di Yogyakarta. Beberapa contoh yang dilakukan oleh masyarakat di Yogyakarta dan sekitarnya, baik secara perorangan maupun atas nama dukuh dapat dicermati di bawah ini (Suwarno, 1994: 249-250):

1. Rumah keluarga Mandoyodipuro di Patehan Tengah No. 12, sejak hari kedua Belanda menduduki kota Yogyakarta dijadikan pos Palang Merah Indonesia. Setelah itu kemudian digunakan oleh Komandan Keamanan Kota untuk markas gerilya.

2. Masyarakat Gamelan Kidul, Prawirodirdjan dan lainnya mendirikan dapur umum secara gotong royong.

3. Keraton sendiri juga membentuk dapur umum yang disebut Sekul Langgen, khusus menyediakan keperluan pada saat SU.

4. Dukuh Bibis di Kelurahan Bangunjiwo Bantul, berada di tengah-tengah antara kota Yogyakarta dan Bantul, daerahnya berbukit-bukit baik sekali untuk markas gerilya, menyediakan rumah untuk asrama tentara dan pejuang lainnya dan membuka dapur umum.

5. Penduduk di Ngasem membantu para pejuang ketika diadakan pembersihan dan pengepungan di wilayahnya yang dicurigai menjadi tempat persembunyian gerilya. Dari pengembangan materi ini mereka yang tinggal di Yogyakarta kemungkinan akan lebih merasa dekat, meskipun tetap dapat dipelajari oleh mereka yang tinggal di wilayah propinsi lainnya. Pada gilirannya nasionalisme dapat dibangun dari 'bawah', dan ini akan lebih kokoh, karena siswa merasa ikut 'memiliki sejarah' lewat keterlibatan orangorang yang berada di sekitarnya, maupun memiliki dan mengenal 'pahlawannya', ada dikisaran sejarah. Penghayatan makna tentang sejarah bangsa tersebut merupakan potensi bagi generasi yang akan datang untuk membuat perspektif masa depan. Selain itu juga dapat membangkitkan kesadaran dalam kaitannya dengan kehidupan bersama dalam komunitas yang lebih besar sehingga tumbuh kesadaran kolektif dalam memiliki kebersamaan dalam sejarah. Disini letak peranan penting sejarah, melihat masa lalu dengan kritis dan proporsional akan dapat memahami kehidupan sekarang dan merencanakan kehidupan di masa datang dengan lebih bijaksana. Sejarah menghubungkan generasi sekarang dengan generasi masa lampau, dan tindakan yang dilakukan dimasa kini hanya dapat dijelaskan dan dimengerti dengan menggunakan referensi masa lampaunya, dan sejarah akan membantu menjembatani rentangan waktu tersebut.

Mencermati peranan Yogyakarta selama revolusi kemerdekaan sebagai enrichment dalam pembelajaran sejarah revolusi dapat diidentifikasi nilai-nilai, seperti nasionalisme, patriotisme, dan toleransi. Sebagai sebuah ikatan kebangsaan, entitas Indon esia tidak pernah ada sebelumnya dan baru muncul pada awal abad ke-20 serta mencapai puncaknya ketika sebuah bangsa dan negara baru di proklamirkan pada tahun 1945. Hal tersebut dilakukan pula oleh sebagian pemimpin nasional dan lokal, serta seluruh rakyat di Yogyakarta yang memilih bergabung dengan Republik Indonesia, menyatukan diri menjadi bagian tidak terpisahkan. Kecintaan dan siap berkorban membela kepentingan republik telah ditunjukkan oleh semua pihak. Dalam hal ini Soekarno, Hatta, Soedirman, Sultan HB IX dan Paku Alam VIII memiliki peran sangat penting dalam sejarah Indonesia, khususnya pada awal kemedekaan. Termasuk di sini adalah penduduk Yogyakarta maupun laskar-laskar pejuang yang berasal dari berbagai daerah bahu membahu melawan penjajah dengan persenjataan yang terbatas. Laskar-laskar pejuang yang umumnya didominasi kaum muda menunjukkan sikap patriotisme, pantang menyerah dan tidak takut terhadap Belanda yang memiliki persenjataan modern. Meskipun yang tergabung dalam laskar-laskar adalah pemuda, dengan latar belakang (suku, agama, budaya) yang berbeda, akan tetapi menunjukkan sikap toleransi, kebersamaan, saling menghargai di antara mereka. Kewajiban dan tanggung jawab terhadap bangsa dan negara telah menyatukan diri mereka untuk membela tanah air.

Ada banyak tokoh nasional, beberapa tokoh lokal, beberapa nama dari masyarakat kebanyakan, perundinganperundingan yang melibatkan pihak Indonesia dengan Belanda seperti: Linggarjati, Renville, Konferensi Meja Bundar dan lainnya, dijelaskan dalam bab tersebut

Sikap yang merujuk pada nilai-nilai nasionalisme dan patriotisme telah diperlihatkan oleh Sultan HB IX, Paku Alam VIII, dan penduduk setempat yang menerima kepindahan ibu kota RI ke wilayah. Termasuk di sini menyediakan tempat bagi pemerintahan provinsi yang sedang mengungsi, contoh adalah pemerintahan provinsi Kalimantan. HB IX dan Paku Alam berasal dari etnik Jawa, akan tetapi berjuang untuk negara dan bangsa Indonesia. Sosok bangsawan yang sering dianggap feodal, akan tetapi berjuang untuk rakyat dan sosok raja tetapi berjuang untuk republik. Wawasan kebangsaan pemimpin tradisional ini terlihat dari sikap tegasnya yang tetap mendukung republik dengan sangat konsekuen. Yogyakarta menyediakan tempat ketika pemerintah RI harus meninggalkan Jakarta, karena terdesak oleh kekuatan Belanda. Yang mereka lakukan semata-mata adalah mengedepankan kepentingan nasional demi tegaknya NKRI. Selama kurang 
lebih empat tahun pemerintah RI sangat tergantung kepada Yogyakarta, baik dalam melakukan perjuangan fisik maupun diplomasi.

Nilai-nilai di atas juga telah ditunjukkan oleh tentara TNI, khususnya dari Divisi Siliwangi yang melakukan hijrah ke daerah republik (Jawa Tengah dan Yogyakarta), dan kemudian melakukan Long March untuk kembali ke daerah Jawa Barat. Termasuk di sini adalah tentara lainnya (TNI) di bawah pimpinana Jenderal Soedirman melakukan gerilya melawan Belanda. Dalam kondisi yang serba kekurangan (sandang, pangan) mereka melaksanakan perintah dan tugas dengan ikhlas. Baik yang hijrah maupun yang melakukan perang gerilya, berkorban jiwa dan raga untuk NKRI dengan meninggalkan keluarganya dalam jangka waktu yang tidak dapat dipastikan. Selain itu juga apa yang diperlihatkan oleh para pemimpin republik ketika ditawan, bersikap tegar, tidak memperlihatkan rasa takut ataupun menyesal karena mempertahankan prinsipnya untuk terus berjuang membela NKRI.

HB IX dan Paku Alam VII secara pribadi memberikan bantuan keuangan ataupun tempat tinggal bagi mereka yang membutuhkan. Termasuk juga sebagian rakyat yang berada di Yogyakarta tidak ragu-ragu memberi bantuan kepada tentara yang datang ke Yogyakarta dalam rangka hijrah, maupun laskar pejung pada umumnya. Dapat dimaknai sebagai bentuk toleransi kepada mereka yang membutuhkan tanpa membedakan status, golongan, pangkat, etnis, agama, dan lain-lain. Mereka menyadari bahwa sejak proklamasi kemerdekaan semua adalah keluarga besar, mereka yang tinggal di bekas wilayah Hindia Belanda itu kemudian menyebut dirinya sebagai bangsa Indonesia.

Terdapat beberapa nilai yang dapat dirujuk oleh siswa dari sub bab 4 ini. Berkaitan dengan nasionalisme dan patriotisme peristiwa Serangan Umum telah menjadi inspirasi bagi pejuang diseluruh tanah air untuk meningkatkan perlawanan terhadap segala bentuk penjajahan. Serangan Umum menumbuhkan kesadaran yang kuat akan pentingnya integrasi bangsa, diwujudkan dengan adanya kerja sama antara kekuatan militer dan sipil dalam perang gerilya di sekitar Yogyakarta. Hal tersebut dilakukan oleh Jenderal Soedirman, HB IX, Paku Alam VIII, Soeharto, Nasution, Simatupang, dan lainnya, bersatu dengan laskar pejuang, para kepala desa, kepala dukuh, ketua Rukun Kampung, dan penduduk yang tidak terhitung jumlahnya menghadapi tentara Belanda. Berkaitan dengan nilai toleransi, misalnya telah diperlihatkan oleh para gerilyawan (TNI dan laskar pejuang lainnya), dan penduduk Yogyakarta yang bekerja sama dan saling tolong menolong selama melakukan gerilya. Meskipun yang satu adalah kelompok tentara dan lainnya adalah dari kalangan sipil atau rakyat biasa, tetapi mereka saling menghormati dan memperlakukan orang lain secara baik.

Contoh berikutnya berkaitan dengan nilai-nilai nasionalisme dan patriotisme telah dilakukan oleh penduduk di desa-desa yang ditempati oleh TNI dan barisan pejuang, mereka mempunyai peranan yang besar dalam menunjang keberhasilan perang gerilya. Selain itu, penduduk di Yogyakarta juga mengadakan perlawanan secara aktif bersama para pejuang menyusup ke dalam kota. Bahkan, dalam keadaan genting mereka melindungi hak milik dan melindungi para pejuang yang sedang bergerilya. Pada tabel 5 dapat dilihat sebagian dari pengorbanan penduduk di Yogyakarta menyangkut mereka yang meninggal, luka-luka, dan yang termasuk juga kerugian harta benda, Untuk nilai toleransi dapat ditemukan pada tindakan penduduk yang secara bergotong royong mengumpulkan uang dan bahan makanan untuk membuat dapur umum bagi para pejuang tanpa dibedakan, sedangkan pada waktu itu kehidupan mereka sendiri sulit. Tindakan ini dapat dimaknai sebagai dukungan tanpa pamrih dan dilandasi keiklasan demi berhasilnya perjuangan dalam melawan penjajah. Selain itu juga mereka sangat menghargai perintah dari pemimpinnya, sebagai contohnya ketika diminta untuk menyerbu kota Yogyakarta pada jam 06.00 dan segera meninggalkan kota pada jam 12.00 tepat. Hal itu segera dilaksanakan oleh segenap penduduk dengan penuh tanggung jawab.

Dari sub bab 5 ini dapat digali beberapa hal yang dapat dijadikan contoh atau panutan bagi siswa dalam keseharian mereka. Yang berkaitan dengan nasionalisme dan patriotisme antara lain telah diperlihatkan oleh para pemimpin, yang dengan keterbatasan mempersiapkan proses pengambilalihan pemerintahan dari tangan Belanda kepada RI, menyelesaikan masalah penarikan mundur tentara Belanda, dan lainnya. Selain itu mereka juga tidak saling berebut kedudukan di pemerintahan, meskipun ada banyak kesempatan bagi seseorang untuk mendapatkannya demi keuntungan pribadi. Semua tunduk pada perintah Menteri Negara Koordinator Keamanan yang waktu itu dijabat oleh HB IX, sehingga tidak terjadi kekacauan. Antara pemerintah pusat (republik) dengan pemerintah Daerah Istimewa Yogyakarta saling membantu dalam menangani masalah di masa transisi ini, yang diutamakan adalah ke pentingan nasional yaitu demi tegaknya NKRI. Suatu tanggung jawab yang berat, ketika sebagian pemimpin republik diasingkan dan yang lainnya melakukan gerilya harus menerima tugas tersebut.

Selanjutnya, nilai-nilai positif lainnya dapat dilihat dari sikap yang ditunjukkan sebagian besar penduduk Yogyakarta, yang bahu membahu tanpa pamrih bekerja keras menjaga ketertiban. Mereka mentaati aturan yang ditetapka pemerintah, sementara para pegawai sipil maupun militer menjalankan tugasnya degan penuh tanggung jawab. Tanpa adanya semangat nasionalisme dan patriotisme, kemungkinan pemerintahan transisi RI tidak berjalan sebagaimana yang diharapkan oleh rakyat Indonesia. Dapat dikatakan pada masa ini tidak terjadi gejolak yang serius di ibu kota RI, Yogyakarta.

Untuk contoh toleransi, siswa dapat melihat dari sikap yang ditunjukkan oleh penduduk yang tinggal di Yogyakarta, mereka menghargai segala upaya atau usaha yang dilakukan pemerintah, seperti mentaati anjuran untuk ikut ronda, tidak keluar rumah pada jam malam, dan sebagainya. Selain itu sebagai miniatur Indonesia dan ibu kota RI, di Yogyakarta berkumpul berbagai etnik yang memiliki latar belakang budaya, agama, ataupun adat yang berbeda. Mereka semua dijamin keamanan jiwa dan harta bendanya tanpa membedakan latarbelakang asal-usulnya dan kedudukannya. Dalam suasana kehidupan seperti itu selama masa transisi tidak ditemukan konflik antar etnik di Yogyakarta. Sikap menghargai pendapat, 
perbedaan, pandangan, dan kebiasaan yang berbeda satu dengan lainnya menjadi kunci utama dari semua itu.

Dari sub bab 6, ini dapat digali beberapa nilai seperti nasionalisme, patriotisme maupun toleransi. Beberapa tokoh nasional dengan gigih dan bekerja keras berjuang lewat jalur diplomasi untuk mendapatkan pengakuan kedaulatan. Dengan memiliki kesadaran tinggi untuk kepentingan bangsa dan negaranya, mereka bersedia mengikuti aturan yang sudah ditetapkan sebagai hasil dari diplomasi bersama pihak Belanda. Perjuangan terus berlanjut ketika beberapa kelompok orang yang tetap setia kepada Belanda mengusik persatuan yang telah ditegakkan sejak masa pergerakan nasional. Tidak ada satupun negara kebangsaan yang tidak pernah mengalami ancaman yang bersifat disintegratif. Berkaca pada sub judul 'pengakuan kedaulatan' nilai nasionalisme dan patriotisme sebagai contohnya, dapat dilihat dengan munculnya kesadaran di masing-masing negara bagian untuk kembali ke NKRI.

Satu per satu negara bagian atas tuntutan dan desakan rakyat bergabung kembali dengan RI karena bentuk federalism bukanlah kemauan rakyat Indonesia. Perubahan dari RIS yang federal kepada RI baru yang berbentuk kesatuan itu mencerminkan keinginan rakyat untuk membebaskan diri dari penjajahan Belanda. Beberapa upaya yang dilakukan oleh pihak-pihak yang pro-federalis (Westerling, APRA, RMS) pada akhirnya berhasil digagalkan oleh pihak RI, dan hapusnya federalis berarti kemenangan mutlak bagi RI yang diproklamirkan pada 17 Agustus 1945. Nilai-nilai nasionalisme dan patriotisme masih melekat pada sebagian besar pemimpin dan rakyat Indonesia, oleh sebab itu berbagai kekacauan politik berhasil diselesaikan meskipun dengan pertumpahan darah di antara anak bangsa.

Selain daripada itu upaya yang dilakukan para pemimpin negara bagian RI dan pemimpin RIS dalam memperjuangkan negara Indonesia yang berdaulat tidak perlu disangsikan lagi. Di sisi lain sebagian besar rakyat Indonesia terus mendukung upaya tersebut dengan mentaati dan menghormati kesepakatan-kesepakatan yang dilakukan oleh pemerintah dengan pihak lain (Belanda maupun $B F O$ ). Baru ketika melalui proses panjang terjadilah kesepakan untuk menghapus bentuk federal dan menjadikan Indonesia negara kesatuan sesuai dengan proklamasi tahun 1945. Pada akhirnya keberhasilan yang diperoleh tersebut karena didukung oleh jiwa patriotisme dari seluruh komponen anak bangsa bukan dengan kekuatan fisik sepenuhnya, namun juga dengan melakukan diplomasi dan menjunjung nilai toleransi, sampai terjadi kesepakatan-kesepakatan menuju Negara Kesatuan Republik Indnesia.

\section{SIMPULAN}

Dengan topik tentang revolusi kemerdekaan di Yogyakarta, siswa mampu menggali nilai-nilai yang ada seperti nasionalisme, patriotism, dan toleransi. Nilainilai tersebut masih relevan dan berguna untuk mengatasi fenomena kehidupan di sekitar siswa, sehingga pembelajaran sejarah menjadi terasa lebih bermakna. Beberapa nilai yang dimaksudkan dapat dilihat dari peran yang dilakukan baik oleh tokoh-tokoh lokal, nasional, maupun masyarakat pada umumnya, yang menunjukkan keteladanan dapat dijadikan contoh bagi siswa.

Pemahaman yang baik terhadap suatu peristiwa sejarah akan menghasilkan secara akumulatif memori kolektif bangsa yang baik pula, sehingga ketegangan-ketegangan antara anggota bangsa atau kelompok sosial yang memiliki potensi kearah perpecahan atau disintegrasi dapat dihindari. Oleh karena itu, untuk kepentingan pendidikan di tingkat persekolahan (dasar dan menengah) cerita sejarah yang dipilih dan disajikan sebagai materi pembelajaran harusnya juga dikaitkan dengan nilai-nilai, tidak semata tentang deretan fakta. Hal ini wajar saja karena nilai merupakan sesuatu yang dipercaya benar dan diangap baik serta diterima secara luas, sehingga materi pembelajarannya tidak diajarkan dalam rentetan fakta-fakta saja, tetapi sebagai gagasan yang dihubungkan satu dengan yang lain.

Dalam proses pembelajaran materi sejarah tidak untuk dihafalkan oleh siswa, setiap peristiwa sejarah syarat dengan nilai dan makna karena berhubungan dengan kehidupan manusia, oleh karena itu mengabaikan unsur nilai akan mempersulit proses identifikasi diri dan jatidiri bangsa. Peristiwa yang berlangsung di wilayah tersebut akan melengkapi dan memperkaya pemahaman terhadap sejarah nasional dan jati diri bangsa. Setiap warga negara Indonesia harus mengetahui peristiwa-peristiwa penting yang pernah terjadi di lingkungan sekitarnya (lokal), begitu juga bagi setiap warga negara di mana saja sangat diharapkan mengetahui sejarah nasionalnya. Oleh karena itu, tidaklah keliru bila muncul pemikiran bahwa sejarah (lokal maupun nasional) harus diajarkan di tingkat persekolahan. Berdasarkan pengalaman orang lain di masa lampau, maka manusia dibekali dalam menghadapi situasi yang sama pada masa kini, memberikan pengertian dan pemahaman, menstimulasi imajinasi serta membentuk kerangka berfikir. Kemampuan-kemampuan tesebut merupakan peneguhan terhadap perlunya pengajaran sejarah sebagai persiapan pendewasaan generasi muda. Memahami manusia merupakan hal penting, sering terdengar seruan-seruan di masyarakat agar belajar dari sejarah, seperti ungkapan Historia Magistra Vitae dari Cicero, yang berarti sejarah adalah guru kehidupan.

Mempelajari sejarah dari bangsa dan negaranya sendiri sangatlah penting karena melalui pemahaman sejarah secara kritis, maka kesadaran nasional dapat dipupuk dan identitas diri maupun nasional akan dapat ditumbuhkan. Ada beberapa faktor yang mendorong individu atau kelompok mengetahui sejarah antara lain: didorong oleh faktor-faktor kognitifintelektual yang menyebabkan seseorang ingin mengetahui apa yang pernah terjadi; berikutnya karena faktor etis-moral yang mendorong seseorang berupaya meningkatkan martabat insan ketaraf yang lebih tinggi. Untuk itu di dalam sejarah perlu menggali dan menemukan nilai-nilai, yang dapat dijadikan pegangan serta landasan untuk berpijak dalam menghadapi situasi masa kini dan melihat kemungkinan ke masa depan. Salah satu yang sekiranya dapat digali keteladanannya dari 
peranan atau sepak terjang para 'tokoh besar' dan orang biasa antara lain adalah nasionalisme, patriotisme, toleransi, kesederhanaan, kegigihan dan lain sebagainya.

Penghayatan makna tentang sejarah bangsa tersebut merupakan potensi bagi generasi yang akan datang untuk membuat perspektif masa depan. Selain itu, juga dapat membangkitkan kesadaran dalam kaitannya dengan kehidupan bersama dalam kominitas yang lebih besar, sehingga tumbuh kesadaran kolektif. Inilah salah satu dari peranan penting sejarah, melihat masa lalu akan dapat memahami kehidupan sekarang dan merencanakan kehidupan di masa mendatang dengan lebih baik. Sejarah menghubungkan generasi sekarang dengan generasi masa lalu, dan sejarah akan membantu menjembatani rentang tersebut. Banyak pihak berpendapat, bahwa mengetahui dan memahami masa lampau merupakan kebutuhan dasar untuk dapat memberi arah yang tepat terhadap perkembangan masyarakat masa kini.

Pada lingkungan persekolahan nilai-nilai kehidupan menjadi begitu penting untuk diperkenalkan dan dipahami oleh siswa sesuai dengan materi yang sedang dipelajari. Nilai adalah kepercayaan-kepercayaan yang digeneralisir, yang berfungsi sebagai garis pembimbing untuk menyeleksi tujuan serta perilaku yang akan dipilih untuk dicapai. Dengan demikian, nilai bagi manusia merupakan landasan atau motivasi dalam segala tingkah-laku atau perbuatannya. Oleh sebab itu, nilai adalah sesuatu yang penting, baik dan berharga, terkandung sesuatu yang ideal, harapan yang dicitacitakan untuk kebajikan. Sesuatu dianggap punya nilai jika itu dianggap penting, baik, dan berharga bagi kehidupan umat manusia dalam berbagai aspek.

Konsekuensi dari pemahaman tersebut menjadikan nilai itu secara praktis sebagai standar perilaku yang menjadikan orang berusaha untuk hidup sesuai dengan nilai-nilai yang telah diyakininya. Semua orang memiliki dan menginginkan nilai-nilai, sekalipun pada sebagian orang tidak selamanya menyadari nilai yang dimilikinya, sehingga menjadikannya terperosok pada perilaku yang bersebrangan dengan nilai yang berlaku pada umumnya. Pada gilirannya nilai-nilai tersebut menjadi bagian integral dalam suatu kebudayaan, sebagai bagian pengalaman yang senantiasa menjadi rujukan terhadap suatu perilaku bagi setiap individu dan masyarakat untuk menentukan suatu perilaku moral. Sebab itu nilai selalu menunjukkan perkembangan dan perubahan seiring dengan kecenderungan dari sikap mental individu dalam masyarakat, serta akan selalu dirujuk untuk menetapkan suatu perilaku bermoral/tidak. Persoalannya bukan bagaimana seseorang harus menemukan nilai yang telah ada tetapi lebih kepada bagaimana menerima dan mengaplikasikan nilai tersebut dalam kehidupan sehari-hari. Nilai itu harus jelas dan harus semakin diyakini oleh individu dan harus diaplikasikan dalam perbuatan, ini menunjukkan pentingnya nilai dalam kehidupan bermasyarakat.

\section{REFERENSI}

Abdullah,Taufik (ed.). 2010). Sejarah lokal di Indonesia. Yogyakarta: Gadjah Mada University Press.

Abdullah, Taufik. 2001. Nasionalisme \& sejarah. Bandung: Satya Historika.

Arif, M. 2008 .Desain Pembelajaran Sejarah berbasis Hiperteks. dalam Sejarah dalam Keberagaman (Penghormatan kepada Prof.Dr.Helius Sjamsuddin, Ph.D, M.A). Jurdik Sejarah UPI: Bandung.

Benjamin. 1991. A Student Guide to History.New York (USA): St. Martin Press

Bogdan, R and Taylor. 1982. Qualitative Research for Education: An Introducyion to Theory and Methode. Boston: Allyn and Bacon

Buchori, M. 1995. Transformasi pendidikan. Jakarta: Pustaka Sinar Harapan.

Bungin, B. 2003. Analisis data penelitian kualitatif. Jakarta: Rajagrafindo Persada

Carr, E.H. 1961. What Is History. New York: Penguin Book

Carreterom, dkk. 2002. Teaching History Through Textbook: Are Mexican an Spanish

Davis, G. A. 2012. Anak berbakat dan pendidikan keberbakatan. Terjemahan ATi CAhayani. Jakarta: Indeks.

Finberg, H.P.R. dan Skipp, V.H.T Skipp. 1973. Local history: objective and pursuit. Newtown Abbott: David \& Charles

Hasan, S.H. 2012. Pendidikan sejarah: liku-liku dan potensi pengembangannya. Dalam Agus Mulyana (Editor), Pendidikan sejarah Indonesia, isu dalam ide dan pembelajaran, (hlm. 87-101). Bandung: Rizqi Press

Jarolimek, J. 1986. Social studies in elementary education. New York: Macmillan Publishing Company.

Kochhar, S K. 2008. Pembelajaran Sejarah, Teaching of History. Jakarta: Gramedia.

Miles, M.B \& Huberman, A.M. 1992. Analisis data kuantitatif, metoda-metoda baru, (terjemahan oleh Tjetjep Rohendi Rohidi). Jakarta: UI Press.

Nursam, M (dkk.) (ed.). 2008. Sejarah yang memihak, mengenang Sartono Kartodirdjo. Yogyakarta: Ombak

Renier, G.J. 1961. History, its puspose and method. London: George Allen Unwin Ltd.

Ricklefs, M.C. 2008. Sejarah Indondesia modern 1200-2008. Jakarta: Serambi Ilmu Semesta.

Sjamsuddin, Helius. 2005. Model-model pengajaran sejarah: beberapa alternative untuk SLTA. Dalam Andi Suwirta dan Didin Saripudin (ed.), Sejarah dalam perubahan, penghormatan 70 tahun Prof. Dr. H. Ismaun, M.Pd., (hlm. 175-194). Bandung: Historia Utama Press.

Sjamsuddin, Helius. 2012. Metodologi sejarah. Yogyakarta: Penerbit Ombak.

Suwarno, P. J. 1994. Hamengku Buwono IX dan sistem birokrasi pemerintahan Yogyakarta 1942-1974, sebuah tinjauan historis. Yogyakarta: Penerbit Kanisius.

Widja, I Gde. 1991. Sejarah lokal suatu perspektif dalam pengajaran sejarah. Bandung: Angkasa 


\section{Murdiyah Winarti}

Mengembangkan Nilai Nasionalisme, Petriotisme, dan Toleransi melalui Enrichment dalam Pembelajaran Sejarah tentang Peranan Yogyakarta selama Revolusi Kemerdekaan

Wineberg, S. 2006. Berfikir historis, memetakan masa depan mengajarkan masa lalu. Jakarta: Yayasan Obor Indonesia

Winecoff, Herbert L. 1987. Values education: concepts and models. (Indonesia \& State University of New York Technical Assistance Program, A World Bank Sponsored Program). Bandung: Fakultas Pasca Sarjana IKIP Bandung.

Wiriaatmadja, R. 2002) Pendidikan sejarah di Indonesia, perspektif lokal, nasional dan global. Bandung: Historia Utama Press.
http://portal.unesco.org/en/ev.php-RL ID=13175\&URL DO=DO TOPIC\&

URL_SECtion=201.html

http://id.wikipedia. org/wiki/Toleransi

http://id.wikipedia. org/wiki/ Patriotisme 